\title{
Pieśni ludowe jako dokument kontaktów Ślązaków z cudzoziemcami i obcymi krajami
}

Anna Tyrpa 
nAPDS Seria XI 2005

\section{Anna Tyrpa}

\section{Pieśni ludowe jako dokument kontaktów Ślązaków z cudzoziemcami i obcymi krajami}

$\mathrm{P}$ ieśni ludowe należą do ustnej odmiany języka. Mają charakter anonimowy. Teksty nie są ustabilizowane, występują w wiclu wariantach. Od inwencji każdorazowego wykonawcy zależy konkretny skład leksykalny utworu. Za kilka dui lub w innej wsi może być on już nieco inny (por. Bartmiński 1973, Ong 1992). Kolejuą cechą pieśni ludowych jest ich charakter wędrowny. Krążą po kraju, nie respektując granic administracyjnych ani nawet państwowych, co jest ważne, gdy się myśli o Sląsku. Należał on do państwa polskiego w latach 990-1348, potem częściowo od 1921, a calkowicie dopiero od 1945 roku. O ile cechy językowe systemów dialektalnych są geograficznie ustabilizowane, o tyle pieśni na ogół nie wiążą się z poszczególnymi regionami. Przy przechodzeniu z jednego do drugiego następuje swoista akomodacja tekstu pieśni: inna fonetyka, często inne słowa, a już najczęściej wymianie ulegają nazwy micjscowości - śpiewak wybiera toponimy najbardziej znane w jego okolicy (Bystroni 1924: 102).

Podstawę materiałową niniejszego opracowania stanowi 13 zbiorów pieśni zebranych na Śląsku. Specjalnie użyto tu określenia „pieśni zebranych na Śąsku”, a nie „pieśni śląskich”, ponieważ ustalenie, które z nich powstaly na Śąsku, a które są wariantani utworów znanych gdzie indziej, nie jest przedmiotem naszych badan. Wykorzystane zbiory zostały wydane w latach od 186.3 (Roger) do 2002 (Dygacz, RŚ). Nie wszyscy zbieracze podaja rok zanotowania poszczególnych utworów, ale na podstawie dostępnych danych można stwierdzić, że najwcześnicj zapisano pieśni w latach czterdziestych XIX wieku, a najpóźniej w latach siedemdziesiątych XX wiekı. Inna sprawa, że czas zapisu mówi tylko o tym, że dany utwór nie powstal później, natomiast jak glçboko sięga w przeszłość - nie wiadomo. Wskazówkami moga być pieśniowe wzmianki o pewnych faktach historycznych lub nazwiska osób o znanych życiorysach. Oprócz zbiorów Lompy, Rogera, Kolberga i Cincia- 
ly z XIX w. i trzech tomów wydanych w latach trzydziestych XX w. (PŚ I-III), pozostałe osiem to edycje $z$ lat ostatnich (1995-20)()2).

Wynotowano z nich wszystkie miejsca, w których występowaly etnonimy (np. Francuz), choronimy (np. Ruś) i przymiotniki (up. uherski). Otrzymano zbiór 150) cytatów, odnoszących się do 20 krajów, narodów czy grup ctnicznych. Tak więc, abstrahując od zagadnienia, które z tych pieśni zostały ułożone przez Ślązaków, uznajemy za istotne, że były na Śląsku znane i śpiewane. Kraje i nacje, występujące w pieśniach śpiewanyclı przez Ślązaków to: Polacy i Niemcy (co oczywiste)', Francuzi, Belgowie i Holandia (co wynika z działań wojennych), Anglia i Ameryka (ze względu na możliwość pracy w czasach bezrobocia), Węgrzy, Słowacy, Czechy i Włochy (jako echo wspólnych losów w monarchii austro-węgierskiej), Cyganie i Żydzi (stale obecni na ziemiach polskich). Pozostałe grupy i krainy pojawiają się rzadziej, z różnych względów, a czasem wydają się czymś odległym, tajemniczym, zgoła mitycznym. Do nich należą: Rosjanie i Turcy, Murzyn, I Iawaj, Asturia i Sardynia.

Przegląd pieśni odnoszących się do cudzoziemców i obcych krajów będzie przeprowadzony w kolejności podanej powyżej.

Przy rozpatrywaniu użycia słów Polsk a, polski, Polacy w pieśniach śląskich zasadniczą kwestią wydaje się stosumek Ślązaków do polskości. Czy się z nią utożsamiają, czy też traktują ją jako cechę obcą, zewnętrzną wobec siebie? Pieśni przeanalizowane pod tym kątem nie dają jednoznacznej odpowiedzi. Można jednak zauważyć pewną tendencję związaną z czasem ich powstawania. W pieśniach zapisanych w XIX wieku Polska traktowana jest jako inny, obcy kraj. Okres I wojny światowej, a zwlaszcza powstań śląskich i plebiscytu przynosi ożywienie związków z Polską, rozbudzenie poczucia polskiej tożsamości.

Oto najdawniejsze zapisy z ballad i pieśni żartobliwych:

1. Mój ojciec jest Bawolski

Z tëjto ziemi od Polski.

To ja jestem syn jego,

Pojedziemy do niego (Rog 74);

2. Przyszła nam z Polski nowina, Że pani pana zabila (PŚ II 4)?

3. Za rzeką, za rzeką, za starym rzeczyskiem Bije Polok Polka starym kopaczyskiem (PŚ II 134);

4. Za Odrą, za Odrą u Poloka, Biją się tam dziewki o chłopoka (PŚ III 63).

\footnotetext{
' Tu warto przywołać artykul A. Grybosiowej (1997), w którym Polaków i Niemców traktuje siç jako sąsiadów Ślązaków. Ślązacy nic są ujęci jako podgrupa lolaków:

2 Rozpatrując wplywy litcratury na pieśí ludową. J. S. Bystroń (1924: 132) pisze, że początek tej ballady wzięty jest z kościclnej pieśni z XV wicku.
} 
Z 1877 roku pochodzi zapis pieśni, w której śląska dziewczyna odrzuca Polaka jako kandydata na męża:
5. Nie chcę Polaka, takiego smyka,
Boć on mocki gada ${ }^{3}$, a jeszcze więcej lyka.
Oto ten pan sztudowany, uczony,
Potrzeja mu filozofki, nie żony (PŚ I 157).

Z kilku pieśni można się dowiedzieć, że Polska jest odrębnym organizmem paústwowym, pobliskim, lecz oddzielonym granicą. Nickiedy przekroczenie tej granicy jest wybawieniem dla Ślązaka.

6. Polska nic daleko, tam ktosik ucieko, przeplynic przez rzyka, jus nie ma Sobcyka+ (PW 139);

7. od zlego Prusa

polska się rusa

granica (PP 104);

8. Powstańcy powstanícy

dobrzy bojownicy,

bijcie się od Śląska

ku polskiej granicy (PP 81);

9. Niechaj cie I Iörsingu jasny pieron strzeli, (...)

że od naszej Polski zbój-grenszuc nas dzicli (...)

Brak nam kul i broni, a pancerny siecze, (...)

szczęśliwy z nas każdy, kto w Polskę uciecze (PP 85).

W pieśni wymieniającej micjscowości Górnego Śląska wspomina się o dwóch miejscach położonych blisko Polski:

10. Skręcisz hetta na Józefka,

stamtąd widać dobrze Polska (...)

W bok Dómbrówki leżą Dołki,

tam już tylko krok do Polski (PW 32-3).

\footnotetext{
${ }^{3}$ Ciekawe, że gadatliwość to jedna z wad, które także wspólcześni Ślązacy wytykają Polakom (Crybosiowa 1997: 87. 88).

${ }^{+}$Byl to klusownik zyjący pod koniec XIX wick a w okolicach Gliwic.
} 
Terror niemiecki w czasic I wojny światowej, a także już po jej zakończeninu, wywołał na Śląsku postawę oporu i wzmogły się dążenia do połączenia z Polską, od której dzielnica ta odpadla bardzo dawno (w XIV w.). Dlatego w jednej z pieśni padają takie słowa:

11. W starych księgach dziś szperają,

czy Ślązak Polakiem,

próżno się o to starają,

boć Lach nam rodakiem (PP 47).

W latach 1919-1921 powstało wiele pieśni, w których wyraża się chęć przylączenia Śląska do dawnej macierzy:

12. My, powstańcy, nie spoczniemy,

aż Śląsk Polsce wywalczymy (PP 96);

13. Bo my tutaj żyjemy

i o polskość walczymy

wciąż (PP 60);

14. A te orgole choćby żaby rechcą,

Górnego Śląska Polsce oddać nie chcą,

a Gómy Ślązek Polsce przypaść musi,

dlatego Ślązok mocno swój miecz brusi (PP 127);

15. A choćby się Noske

postawił na glowie,

będziemy mieć Polska

jak nasi ojcowie (PP 129);

16. My stoimy wszyscy wraz

pierś przy piersi w każdy czas,

bronić swego do ostatka,

bo tak każe Polska-Matka! (...)

Hej Ślązacy wnet już wraz

z Polską Śląsk złączymy nasz (PP 39).

21 marca 1921 roku odbył się plebiscyt, który miał zdecydować o przynależności poszczególnych powiatów do Polski bądź Niemiec. W okresie poprzedzającym go powstało wiele pieśni patriotycznych, które w jakimś stopniu miały być przeciwwaga dla bezpardonowycl dzialań administracji niemieckiej. 
17. Dziś w plebiscycie świat nam uwierzy,

komu po prawie Ślązek należy,

bo my za Polską glos nasz oddany,

Polsce na wieczność ślub nasz oddany,

Polsce na wieczność ślub nasz skladany (PP 83);

18. Marsz, marsz Polacy,

marsz do glosowania.

Głosy Polsce dajemy,

dość już uciskania.

Plebiscyt pokaże,

że nas nikt nie zdusi,

święta ziemia śląska

Polsce przypaść musi (PP 55);

19. Nie wychwalajcie nom tej waszej niemczyzny, my oddamy kartka dla polskiej ojczyzny (PP 86);

20. Dziś plebiscyt odbywany,

Polsce przysięgamy,

a Prusakom w nasze prawa,

mieszać sie nie damy (PP 29);

21. Za Polską glosujcie,

Niemca sie nie bójcie.

Niemiecz precz stąd musi,

a Polska tu wróci (PP 59).

W okresie powstań i plebiscytu w pieśniach śląskich akcentuje się polskość Śląska i Ślązaków. Realizuje się ten pogląd na różne sposoby. Jednym z nich jest podkreślanie jedności mowy i pieśni:

22. Nysa, Prudnik i Glubczyce, Kietrz, Baborów, Leśnica, Eabędy i Pyskowice, Kędzierzyn, Zdzieszowice, wszędy dobrzy lıdzie są, jako tako się maja, w poczciwości se żyją i po polsku godają (PK 165);

23. Juz dom jest zdobyty, sztandarem okryty, polska pieśń już glośnieje (RŚ 129);

24. Odra i Nysa granicą nam będzie, Bóg dopomoże wroga nam zgnieść, 
śpiew polski wtedy nam rozebrzmi wszędzie

wolności naszej niech będzie cześć! (PP 41).

Innym sposobem jest mówienie o polskiej krwi i sercu:

25. Dowalki, marsz, o świętą ziemię,

o święte chaty, święty siew,

o śląski lud, piastowskie plemię,

o serce polskie, polską krew! (PP 79);

26. W Halembie, w Ialembie

przesmutno sie dzieje,

bo na równej drodze

krew polska sie leje (RŚ 137);

27. A na Górę Świętej Anny dróżyneczka bieży,

siła, siła tam powstańców z polskim sercem leży (PP 13).

Wspomina się też polskie godło:

28. A ty legniesz, kochaneczku, w ziemi pod Opolem, polski orzeł roztopierzy skrzydla nad twym grobem (ŚP 65).

I wreszcie wiele razy mówi się w pieśniach powstańczych wprost, że między Ślązakami i Polakami można postawić znak równości:

29. Ślązoki, Ślązoki, wszyscyśmy Poloki, nie zmoga nos nigdy te juchy Prusoki (PP 132);

30. Idźcie se do Berlina, dlo wos chleba tu nie ma, bo na Śląsku Ślązoki to są same Poloki (PP 130);

31. Matko Boska polska, ratuj nas Polaków, wygoń z naszej ziemi tych pysznych Prusaków (PP 56); 
32. Oni mówią, że niewinni, że wine ponoszą inni, jednak my, Polacy, myślimy inaczej (PP 73).

Również choronim Śląsk łączony jest z przymiotnikiem polski:

33. Tukej Polska jest od Piasta, (...)

a Śląsk polski jest i basta (PP 51).

Niewątpliwie tematyka polska najobficiej występuje w pieśniach z czasów, gdy ważyły się losy przynależności państwowej Śląska. Wzmianki o Polsce trafiają się jednak i w nowszych utworach, z czasów bezrobocia w latach trzydziestych:

34. Jeszcześ nic nie sprzedol, już uciékać musisz,

bo gazy do szybu policjon ci wrzucit.

byś wiedziol, że w Polsce tyż jest bezrobocie,

A po gazach patki nie roz są w robocie (RS 110),

a nawet ze szczęśliwych lat powojennych w Polsce Ludowej:

35. Tóż se górnik dzisiej w Polsce dobrze żyje i podwyższo cięgiem normy i rekordy bije (PG 58);

36. Waglo nafedrowot cale dwie tony, już go kolej wiezie w pomorskie strony, za wạgiel węgorza chce $z$ polskiego morza, dla sia i żony (PCi 109).

Liczba piéśni, w których mowa jest o $\mathrm{Nic}$ m a ch, przekracza znacznie liczbę pieśni o innych marodach. Występują oni pod wieloma nazwami: Niemcy', Gérmanié, Prusourie', Prusacy; pojawia się też choronim Saksy' i przymiotnik saski. Najczęścicj etnonimy te i derywaty od nich pojawiają się z epitetami o wybitnie negatywnym charakterze. Nie sposób przedstawić tu wszystkie zebrane fragmenty. Niektóre z nich zilustrują różne aspekty odniesień Ślązaków do Niemców. Jako pierwszy wymieńmy fakt zajęcia śląskiej ziemi przez Niemców:

37. Przyszli tu przed laty te pruskic psubraty, 
bili nas, dręczyli

jak najgorsze katy (PP 110);

38. Przyszli Niemcy do kraju (...)

według swego zwyczaju.

$\mathrm{Z}$ cielęcymi torbami,

teraz chcą być panami (K 43 Śl 55)

39. Kraj zabrali nam Prusowie,

nasi marni sąsiadowie (PP 103).

Winą zajęcia Sląska przez Niemców obarcza się Polaków:

40. Polacy, Polacy, coście wy zrobili, iżeście wy Niemców do Polski wpuścili? (PP 71).

Konsekwencją panowania Niemców stał się obowiązek służby wojskowej w pruskiej armii przyjmowany jako zto konieczne, o czym mowa w wielu pieśniach wojackich:

41. A czym ja jest pies pruski, związali mnie w lańcuszki, do wojska mnie pognali i karabin mi dali (PW 25);

42. Oto, wojacy, rekruta macie, tak go nauczcie, jak sami znacie (K 43 Śl 50);

43. Jeszczech jo nie uróst, jużech wojok szyją mi na wojna, szyją mi na wojna pruski kabot. Pruski kabot modry, modrusienki, ej, nie widać końca, ej, nie widać końca tej wojenki. (PP 70);

44. Już ja wam dziękuje, kochani rodzice,

${ }^{5}$ Wedlug J. S. Bystronia (1924: 124) pieśń ta pochodzi z końca XVIII w. i jest powszechnie znana w Polsce. 
Bo ja już iść muszę

Na saską granicę ( $\operatorname{Rog} 21)$.

Zastanawiający jest następujący tekst:

45. Kiedyśmy jechali trzysta mil za Berlin (...)

Bez gwery, kanony, bajnety i piki

Wojak śmialo iść musi,

Za swój kraj i swoją najmilejszą

Krew swoją przelać musi (PŚ II 206).

O jaki kraj tu chodzi? Pieśń zostala zapisana w 1904 roku. Czy autor miał na myśli państwo niemieckie, czy może Śląsk - swoją malą ojczyznç?

W niektórych utworach słychać skargi na nielitościwe traktowanie ludı przez rządzących Nienców:

46. Dość nas German prześladowal, znilowania dla nas nie mial, myśmy wszystko znosili (PK 45);

47. bo German, sobaka, drze skóra z Ślązaka (PP 48);

48. Biją glosy, zicmia jęczy,

Prusak śląskie dzieci męczy (PP 97).

Śląskie powstania staty się kanwą dla bardzo licznych pieśni, w których pełna rezygnnacji postawa gnębionych Ślązaków zmienila się w nastawienie waleczne, wolę rozprawienia się $z$ wieloletnim wrogiem:

49. A jo wiem, co zrobia,

za tego wojoka,

obróca strzelbiczka

naprzeciw Prusoka (RŚ 136);

50. Wygnać, wygnać,

pruskiego Germana,

z ziemi śląskiej

aże do Poczdama (PP 122);

51. Wyostrzyjmy miecze,

niechaj krew pociecze, 
damy Prusom lanie,

pódźmy na powstanie (PP 57);

52. Minz̨ł czas udręki

$z$ tej prusackicj ręki,

wyrwijmy się, bracia,

z tyrańskiej paszczęki (PP 110).

Inne pieśni powstańcze wyrażają triumf zwycięstwa nad Niemcami:

53. Dej se pozór, Wiluśku",

poczynej pomaluśku,

byli tu juz tacy,

odważni Prusacy,

dzisiej leżą se w piosku (PP 116);

54. I Iej, Germany, wielkic pany,

wasze zgnietliśmy kajdany (...)

Na kapuście drobne liścic,

zamiast wygrać, przegraliście (Pl 123).

W latach 1930-33 panowało na Śląsku bezrobocie. Wielı lıdzi musiało jechać w gląb Niemiec w poszukiwaniu pracy. W pieśniach odzywają się żale tych biednych, wyzyskiwanych najemników:

55. Ojciec bezrobotny, w domu straszna bieda,

zaden kupiec w sklepie nic na kredyt nie da (...)

Ci jadą na Saksy, ci do Ameryki,

bo u nas nieczynne kopalnie, fabryki (PG 31);

56. Ludzie powiadają, że tam w Prusach dobrze, a tam trzeba robić, aż sie skóra podrze (PL 124);

57. Żeby tam na Śląsku

fabryki rusyly,

to by nase rynce,

w Miemcach nie robily (PP 75).

"Zauważmy, że określanic cesarza zdrobnialym imicniem ll'illuśs stosowane też bylo przez Haškowego Szwejka. Czy jest to rzcezywiście dowód ..przylgniçcia do szcroko rozumianç kultury niemieckicj”, „więzi nawykowej z państwem niemicckim" (Grybosiowa 1997: 86), czy może wyraz spoufalania się, a nawet lekceważenia wladzy? Por. dalcj cytaty $n$ r 73, 75. 
Pojawiły się też pieśni lżejsze w tonie, w których rozpatruje się Niemca jako kandydata na męża dla śląskiej dziewczyny. Oczywiście wynik jest negatywny.

58. Niemca też nie chcę, bo jest wódką zlany,

Ma fraczek krótki, wyfryzowany,

Niemiec skacze, ma twarzyczkę jak róża,

Ale dla mnie broń go Boże za męża (PŚ I 158);

59. Miemczyka nie chcę, bo zimny wale,

A ja z przeciwna ogniem się palç.

Niech się Miemczyk pod pierzyną wygrzewa,

A ze mnie żonki niech się nie spodziewa (PŚ II 150);

60. Jo ci powiadom, jo ci powiadom, nie bier se Germana (P' 48).

Państwo polskie nie prowadziło wojen przeciwko Francj i. Jednak pieśni ludowe obrazıją sytuację prostych ludzi, również młodych mężczyzn z zaboru pruskiego i austriackiego. Ci byli powolywani do armii i musieli walczyć z Francuzami. Pieśni zcbrane przez Rogera przypominają wojnę z 1813 roku (Rog 22), a te późnicjsze być może wojnę francusko-pruską z lat 1870-1871. Niektóre z nich formułuja ponure przewidywania co do rozpoczynającej się wojny:

61. Już na mnie celıja

Francuscy katowie (...)

Bo ja już iść muszę

Na saską granicę (Rog 21);

62. Lękają się oni,

Bo też mają czego

Wiedzą że nie ujdą

Ognia francuskiego $(\operatorname{Rog} 22)$;

63. Ty już z wojenki nie przydziesz,

bo z Francuzami wojna jest,

To zginiesz (PŚ II 433);

64. Francyo, Francyo!

W nieszczęśliwym landzie

Niejedna dziéweczka

Syneczka pozbędzie (Rog 28); 
65. Jak já pojadę na francuza,

Bedzie plakać moja Zuza,

Bedzie plakać, narzekać

Jak mie bedą oblckać (Zb IX 264).

Tylko jeden cytat ma wydźwięk optymistyczny:

66. Szabliczka bruszona -

To jest moja żona,

Ona się wyrąbie

Między Francuzoma (Rog 12).

Inne pieśni opowiadają o przebytych już bojach:

67. O! ciągli Francuzy,

Nawet i Rusy:

Niejedna maciczka

O swego syneczka

Serce zasmuci (Rog 15);

68. Szabliczka bruszona,

To jest moja żona;

Boć mię ona broniła,

Jak był Francuz doma ( $\operatorname{Rog} 28)$;

69. Bylem ja wojaczkiem

Trzy mile za Pragiem

Wygnałem Francuza

Ze swoją armatą $(\operatorname{Rog} 2(0)$;

70. Aj, ty nie najdziesz u nas miłego,

W bitwie przebodli Francuzi twego $(\operatorname{Rog} 11)$;

71. Dy mie nie zabili

Na francuskich tąkach

To mie nie zabija

Mej panience w rękach (Zb IX 255).

Przebywanie śląskich mlodzieńców we Francji budzilo czasem zazdrość pozostalych w domu panien: 
72. Od Francyje jadę, szabelkę toczę, obróć mi się, miła, obróć mi się, miła, niech cię zobaczę.

Ja się nie obrócę, boch nie powinna, niech ci się obróci, nich ci się obróci z Francyje inna.

Nie było tam czasu inne milować, boć tam trzeba bylo, boć tam trzeba bylo eksycyrować (PK 258).

Jest też pieśń o powrocie z I wojny światowej:

73. Glupi Wiluś myśloł, iż mu byda służyć, pójda sobie do powstanio, aż sie bydzie kurzyć (...)

Ida spod Werdonu Ida se z Francyje,

a tu na mie dziwnie patrzą te rube bestyje (PP 12()).

W okolicach Bytomia zanotowano pieśń, której bohaterka wyraża dezaprobatę wobec Francuza jako kandydata na męża:

74. Francuza nie chcę, bo wódką zlany, Ma fraczek krótki, włos pudrowany.

W taniec idzie, twarz mu kwitnie jak róża, Ale mi jego broń Boże za męża (PŚ II 149).

Pieśń ludowa utrwaliła choronim Holand ia z powodu wydarzenia historycznego, które bardzo obeszlo mieszkańców Śląska pruskiego. Otóż 9 listopada 1918 roku, po wybuchu rewolucji w Niemczech, król pruski i cesarz niemiecki Wilhelm II został pozbawiony tronu i zbiegł do Holandii, gdzie abdykował 28 listopada. W 1935 roku w Lublińcu śpiewano o tym tak:

75. Idzie do I Iolandie, kijem się podpiero, cylinder na głowie koúskie butki zbiero. (...) 

Wiluś w Holandyji
drobno drzewo rąbie.
Widzisz, kajś zajechol,
ty królewski gląbie?
Wiluś w Holandyji
śledziami handlıje.
Widzisz, ty pieronie,
jak ci to pasuje? (PP 125).

Być może ostatnia zwrotka powstała w związku z utrwalonym porównaniem u'yglada jak śledź holenderski (NK III 796). Warianty pieśni zanotowano jeszcze w 1947 i 1954 roku (PP 117, 134).

Ponadto w pieśni gaikowej występuje jakaś pani Olenderka, przy czym trudno dociec, czy to etnonim, czy nazwisko:

76. Na naszym goiku malowane jajka,

co je malowała pani Olenderka (ŚP 27).

Belgowie zostali wspomniani w pieśni mówiącej o tym, jak stawili opór armii niemieckiej posuwają̧ej się do Paryża:

77. Cysorz Fryderyk Willıelm (...)

Tak sobie zamierza:

pójdę do Paryża,

tam i na swaczyna

dostaniemy wina (...)

Ale Belgijoki

to chłopy jak dęby,

wyszli go przywitać,

wytrzaśli mu zęby (PP 115).

Wzmianki o Angli i pojawiają się w dwóch kontekstach. Pierwszy to smutna historia górnika, który musial szukać pracy w obcym kraju i tam poniósł śmierć, osierocając rodzinę:

78. ojciec mi odjechoł do cudzego kraja.

Do cudzego kraja, bali pod Anglika,

dość sic tam natyroł w kopalniach, fabrykach. (...)

W tym nadeszło pismo z przesmutną nowiną,

że on legł w kopalni pod anglicką ziemią (RŚ 55). 
Drugi to pelne goryczy wyrzuty powstańców wobec Anglików, trzymających niemiecką stronę podczas powstań śląskich:

79. O cześć wam szaclıraje z Londynu

za strugi krwi śląskiej przelane (...)

My raczej kopalnic i huty lichwiarzy

wysadzim w powietrze petardą,

nim Prusak i Anglik swym knutem się waży

naruszyć powstańca cześć hardą (PP 77).

A me r y ka (w znaczeniu Stanów Zjednoczonych Ameryki Pólnocnej, a nie kontynentu) występuje w trzech pieśniach śląskich. Pierwsza z nich to skarga bezrobotnych, dla których jedną z dróg wyjścia jest wyjazd do pracy za granicę (nr 55). Pieśń tę zapisano w 1969), ale powstała zapewne w okresie międzywojennym.

Druga to utwór żartobliwy, będący radą dla mężów mających kapryśne żony. Ameryka jest krajem, gdzie można zdobyć dobre lekarstwa:

80. A ty pójdziesz, mój mężyczku, do Ameryki (...)

W Ameryce sporządzaja najlepsze leki (..)

A mężyczek wziął kij w ręce, uzdrowił żonka (...)

Tu mosz leki z Ameryki, już zdrowa żonka (PW 117).

W trzeciej mowa o poszukiwaniu ukrywającego się człowieka. Jedıą z moźliwości jest jego ucieczka do Ameryki:

81. Wiesz kaj Ameryka? Tam szukaj Sobcyka (PW 138).

Odniesienia do W ę gie r mają w śląskich picśniach różny charakter. Jest w nich mowa o węgierskiej ulicy (nie wiadomo, czy to urbonim, czy ulica na Węgrzech):

82. Wandrowali szewczycy po węgierski ulicy (PŚ I 77).

Jest mowa o terenie za granicą:

83. Na uherskij stronie, niedaleko zamku

Pasie tam syneczek kónie w macierzanku (PŚ I 474).

Z Węgier widać przybywali na Śląsk Cyganie, skoro panna chce im sprzedać swego zalotnika: 
84. Uherscy cygóni, przedóm wóm galana (PŚ II 383).

Pewien szczegół urody określa się jako węggierski:

85. Jest tam żonka bogata,

Jyny troszke klupata. (...)

A nosek mo węgierski,

Jak ogórek za czeski? (PŚ III 72).

Wspomina się też o Węgrach jako o partnerach handlowych:

86. W Jabłonkowie są Jackowie,

Rozumieją każdej mowie,

Handlują z Węgrami, z Turkem,

Szli na szańce z Brandeburkem (Zb IX 278).

Etnonim Slowacy występuje tylko w pieśniach ze Śląska Cieszyńskiego:

87. Beskidzie, Beskidzie,

Co po tobie idzie?

Słowiáczek z koniami

Jedzic za saniami (Zb IX 245).

W kolejnym przykladzie odnosi się on do formacji wojskowej:

88. Około naszego domu jadą wojacy,

Mają biołe wyłożenia, są to slowacy (PŚ I 269).

O związkach Ślązaków z Czecha mi i W lochami wspominają pieśni z Ustronia i okolic Cieszyna, dotyczące marszów wojennych armii austro-węgierskiej:

89. Kamaraci w roce idą do Czech (Zb IX 284);

90. Jak pomaszerują trzysta mil za Wiedniem.

Nic tam nie uwidzą jen taljańską ziem.

Talijańska ziemia — piękne polożenie (PŚ III 517).

\footnotetext{
Niewykluczonc, że w tym opisic mało ponçtnej kandydatki na żonç odzywa się stereotyp brzydkich Węgicrek (Niewiara 2000: 199).
} 
Cygan ie byli obecni na Śląsku, dlatego zapisano sporo pieśni, których są bohaterami. Najstarsza pochodzi ze zbioru Juliusza Rogera (1863) i jest jakby manifestem grupy, która sama określa swoje pochodzenie, tryb życia, upodobania i stosunek immych do siebie. W pieśni tej zachowal się mit o egipskiej genealogii Cyganów, będący elementem ich autoprezentacji już od XV wieku (Mirga, Mróz 1994: (55-73) ${ }^{\circ}$ :

91. Myśmy są cygani,

Z Egiptı wygnani (Rog 58).

Wiadomo też, że prowadzz̨ oni wędrowny tryb życia:

92. Przeto nasze życie

Jest światowe bycie (Rog 58);

93. Zjechol cygon z cudzych krajów (PL 120).

W pieśni mowa jest o wspólnotowym życiu Cyganów:

94. W gromadzie chodziny, hu! (Rog 58).

Wymienia się takie rysy życia Cyganów, jak nieposiadanie ziemi ani domu:

95. Nie kochamy gmachy (...)

W polu nocujemy, hu! ( $\operatorname{Rog} 58)$;

96. Hej, tam pod lasem coś błyszczy z dala,

banda Cyganów ogień rozpala (...)

Cygan bez roli, Cygan bez chaty (BŚ 206);

97. W lesic pod jaworem

Tam cygani grają. (PS III 166).

Co do sposobu zarabiania na życie, to z pieśni zebranych na Sląsku można się dowiedzieć, że

98. Cygan nie sieje, Cygan nie orze (BŚ 206),

\footnotetext{
* Przekonanic o pochodzenin Cyganów z Egiptu znajduje potwierdzenie w języku angielskim: etnonim Gipsy, Gypsy' wywodzi się z przymiotnika Esyptian.
} 
ale

99. Cygon robi kotly, tygle (PL 120),

a przede wszystkim gra, śpiewa i tańczy:

100. jedni śpiewają, drudzy tańcują (...)

Słychać gitary i kastaniety,

grają mężczyźni, tańczą kobiety (BŚ 206);

101. Pójdę do gospody

Tam cyganie grają (PŚ III 166);

102. Zagraj mi piękny Cyganic,

zagraj mi piosnkę sprzed lat (BŚ 232).

Ciekawe, że w pieśni zapisanej okolo połowy XIX wieku umiejętność wróżenia z kart przypisuje się mężczyźninie:

103. Choć cygan ożarty, hu!

Rozumié klaść karty, hu! (Rog 58),

podczas gdy w nowszych pieśniach stało się to specjalnością kobiet:

104. Tyś jest cyganka, co wróżyć umiesz,

To, co w lesie rośnie, wszystko rozumiesz.

Wywróż mi, cyganko, wywróż mi z tej ręki! (PŚ II 583);

105. Piękny chłopcze, daj se wróżyć,

Podaj rączkę swoją!

Cyganka ci prawdę powie,

Zna osobę twoją (PŚ II 584).

Sposobem na przetrwanie jest też chodzenie po prośbie:

106. cygon prosi, cygon mo,

cygonowi każdy do (PL 120).

Ambiwalentne są opinie o bogactwie Cyganów. W pieśni cieszynískiej chłopiec zamierza poprosić Cyganów o rozmienienie na drobne znalezionego dukata, bo: 


\section{Cygani ożrani,}

a pieniądze mają (PŚ III 251);

na co słyszy radę:

108. Pójdź, syneczku do dom,

Zaniechaj cyganów,

Cyganie ożrali,

Pieniędzy nie mają (PŚ III 166).

Również w innej pieśni padają słowa:

109. Cygan szczęśliwy, choć niebogaty (BŚ 206).

Pieśni śląskie rejestrują niechętny stosunek do Cyganów, znanych z oszukiwania i kradzieży:

110. A cygani są źli ludzic,

Wychowują dzieci w budzic.

A cygani po wsi chodzal,

Kogo mogą to uwodzą.

I nas też tak uwodzili,

Bo nam kurę z sieni wzięli (PŚ III 10);

111. A cyganie światem idą,

Kogo mogą, to oszydzą (PŚ III 171).

W żartobliwej pieśni dziewczyna chce się pozbyć zalotnika, sprzedając go węgierskim Cyganom (nr 84).

Mimo zlego traktowania, Cyganie nie chcą przyjąć cudzych wzorów:

112. Choć nam nic nie przają.

Ze wsi wyganiaja,

Od wsi do wsi żena, hu!

Jednak nas nie zmienią, hu! (Rog 58).

Osobnym zagadnieniem jest miłość. Może ona dotyczyć przedstawicicli tej samej grupy etnicznej:

113. Cygan z wojenki powrócit,

Cyganki nie zastał juz. 
Inny jej głowç zawrócit,

Inny pokochał ja już (BŚ 232).

Może łączyć Ślązaka i Cygankę:

114. Z tamtej strony Wisly Cyganeczka tonie, gdybym mial lódeczkę, popłynąłbym do niej.

Nie mam ja lódeczki, ani wioseleczka,

utonie, utonie, moja Cyganeczka (BŚ 201);

115. Stóń, miluśko, dej mi lognia,

Tegoś, cyganka moja, jesteś godna (PŚ II 396).

Niekiedy takie uczucie napotyka sprzeciw otoczenia, które chce zakochanego chlopca przywolać do porządku:

116. Masz dómu kopaczku

Masz dómu oraczku,

Jyny ty zaniechaj

Czernu cygóneczku!

Kopaczku, oraczku

To ja mam każdy dzień

Z czarnym oczkiem dziewczyn

Jyny roz za tydzień (...)

Czorną cygóneczkę

Miłować mi dejcie (PŚ III 166).

Osobę wyznania ewangelickiego porównuje się do Cyganki. Inna religia i egzotyczna uroda są przeszkodą do osiągnięcia jedności:

117. Żebyś byla katoliczka

Całowalbym twoje liczka

Ale żeś jest luteranka,

To wyglądasz jak cyganka (PŚ III 10);

118. Kiebyś była katolicka,

Wzionbych cie se za żonicka.

Ale tyś jest lutryjanka

Mos ty ślepka jak cyganka (PŚ III 8).

Użycie przymiotnika cygański w kolejnych fragmentach pieśni niewątpliwie jest znakiem wartości ujemmej: 
119. Tam mi się trafiala wdowa, (...)

Bogato, garbato.

Na dwa oka świdrato.

Była rodu dalekiego,

I to stanu cygańskiego (PŚ II 4(0));

120. Jo móm bótki piekne, kordybański.

A ty jyny papucie cygaúski (PŚ II 189).

Żydz i do II wojny światowej stanowili grupę etniczną obecną na polskiej ziemi. 1)latego i w pieśniach śląskich są oni obecni. Teksty folkloru dokumentują ich role zawodowe na wsi: prowadzenie karczem, handel, pożyczanie pieniędzy pod zastaw.

Fragmenty pieśni dokumentujące postać Żyda-szyukarza to:

121. Poszla dziéweczka

Po gorzaleczke

Do żyda, do żyda (Rog 246);

122. O nieszczęsua Biedo,

Idźże ty do żyda.

Iarędarzu żydzie,

Wyrozum tëj Biedzie,

A daj jéj gorzalki (Rog 240);

123. Powiadają wszyscy ludzie,

że mi liczka zbladly.

O nie zbladly one mi

U żyda na trunku (Rog 226).

Dokumentacja tekstowa dla Żyda-handlarza:

124. U sąsiada szwarne dziołchy,

Nie mają smaku.

Przyjechal żyd obtargany,

Nabrał ich wóz obk tadany,

Pojechat na targ (PŚ III 55)";

125. Miałach ja kochanków, jak na lipie kwiatów,

Takiego istego nie godzi siç światu,

${ }^{9}$ O tej żartobliwej picśni pisze Bystroń (1924: 108), że rozpowszechnili ją flisacy. 
Ale jo mu rada dóm, jo go żydóm zaprzedóm.

Wy, krakowscy żydzi, galana wóm sprzedóm (PŚ II 623);

126. Ej wy, polscy żydzi, przedom wam galana (PŚ II 576);

127. Buty wykrzywione (...)

"Zegarek zepsuty".

"Zaniés go durniu do zyda,

A kup sobie buty." (PŚ III 27);

128. Bez zagródki i bez pola ciężko żyć z wycugu,

na borg trza by brać u żyda

a mieć nie chca długu (PW 49).

Żyd jako ten, $n$ którego można pożyczać pieniądze, pojawia się w następującym fragmencie:

129. Choćby się i żydom zastawić,

Gdyby jeno piękne szaty sobie sprawić ( $\operatorname{Rog} 257)$.

W pieśniach śląskich są wzmianki o tym, że małżeństwa mieszane nie są pożądane:

130. Kiebyś była katoliczka (...)

Miłowalbych twoje liczka (...)

Aleś ty jest żydóweczka (Rog 163).

Ministranci chodzący po kolędzie zachęcają panny do hojności, bo:

131. Która nic nie daruje,

Szczęście sobie popsuje;

Bo się jak żyw nie wyda,

Choćby chciała i żyda (Rog 212).

Dwie żartobliwe pieśni opowiadają o Żydach w związku z żurem. Czy to przypadek, czy też była to ich częsta potrawa?

132. Posmutnialy wszystkie żydy (...)

Od czego takiego?

A od żuru kwaśnego! (PŚ II 400));

133. Szla żydówka koło muru, wyloła se gornek żuru, 
Żyd sie śmiot, aż sie chwiot.

mycke zjon, w pół sie zgion (PK 169).

Tylko jeden zapis pieśni wojackiej z użyciem etnonimu R us y nawiązuje do rzeczywistych wydarzeń, prawdopodobnie wojen napoleoniskich, skoro pochodzi ze zbioru z 1863 roku (nr 67).

Etnonim ten pojawia się te $\dot{z} \mathrm{w}$ balladzie o dziewczynie przemienionej w drzewo:

134. Wędrowali Rusy,

Trzy szwarui karlusy $(\operatorname{Rog} 70)$.

Kolejne cytaty pokazują, że Ślązacy nie utrwalili w pieśniach swoich osobistych doświadczeń, a nawet Ruś jest dla nich jakąśs mityczną krainą:

135. A ta nasza Marusina

Spadła z picca na Rusina (PŚ III 187):

136. Lecialy gęsi z Polskiej do Rusi,

Wołały, gęgały naszej Hanusi"' (Lom 273);

137. Siodłam konia siwka, piję krygiel piwka. Pojadę do Rusi.

Do Rusi, do Rusi, do Jeruzalemu (PŚ II 406).

Zarejestrowano na Śląsku dwie pieśni o porywaniu przez Turków dzieci i panien do niewoli:

138. Dwoje ślicznych dziatek do Turek zajali (Lom 187);

139. Matki co ceruchny macie

Turkowi ich nie dawajcic.

Boch jo jeno jedna miala

Turkowich ją dać musiala (PŚ I 96).

Jan Stanisław Bystroń uważa, że motyw niewoli tureckiej nie jest wlaściwy polskim pieśniom i że musial przyjść do nas ze Słowacji lub Rusi (PŚ I 96, 97).

Turcy występują w zapisanej w kilku wariantach balladzie o dziewczynie zamienionej w drzewo:

"'B. Zakrzewski podaje, że to jedna z najbardzicj popularnych pieśni polskich pochodzenia szlacheckicgo, upowszechniona wśród ludu (Lom 273). 
140. Wandrowali Turcy

Trzej kraśni mlodzieńcy (PŚ I 88);

141. Wędrowali Turcy,

Przekraśni inłodzieńcy (PŚ I 88);

142. Wędrowali Turcy,

trzej szwarni mlodzieńcy (PL 100);

143. Nie bijcic mnic, Turcy, wy, straszni mordercy (PŚ II 56).

Pojawiają się też w pieśniach o miłości:

144. Miala jo, miala, mojiczek,

Co mi go stroil Janicek (...)

Na samym wyrszczku leluje,

Przyszli tu Turcy z Galije.

Cóż wy tu Turcy robicie,

Moji leluje targocie! (PŚ III 228);

145. Przyjechali trzej turowie, wszyscy pod piórami,

Darowali naszej pani skrzynię z talarami (PŚ III 167).

W okolicach Cieszyna zapisano pieśń towarzyszącą tańcowi skakanemu:

146. Jedzie Turek po granicy,

Szabla sie mu blyská;

Stare baby uciekają

A on sobie wyská (Zb IX 237).

W innej pieśni z tej samej okolicy mówi się o handlu z Turkami (nr 86).

Slowo Mur z y n służy jako przezwisko brudasa w tekście utrwalonym koło Olesna:

147. Po cóżeś tu przysed, ty czarny murzynie?

Nie śmiesz ci ty leżyć przy moij pierzynie!

Bo moja pierzyna wstążką obszywana,

A twoja koszula trzy lata nie prana (PŚ II 342).

Wśród pieśni biesiadnych śpiewanych w Bojszowach znalazła się i ta o H a waju . Oczywiście nie ma tu mowy o osobistych doświadczeniach, można jednak przypuszczać, że za jej pośrednictwem Hawaje zaistniały na mapie mentalnej Ślązaków. 
148. Tam pośród gór I Iawaj, jest piękny kraj, a w nim I Iawaj! Hawaj jest piçkny, I Iawaj uroczy, I Iawaju powiedz mi, czy kochasz muie (BŚ 228).

W tym samym zbiorze pieśni znalazla się Asturia, poświęcona krainie w pótnocno-zachodniej I Liszpanii, wsławionej strajkiem gómików z 1934 roku i udziałem w wojnie domowej z lat 1936-1939.

149. Asturio, ziemio mych młodych lat,

Asturio, ziemio jedyna,

do mojej ziemi chcę wrócić wnet i wrócę, jeśli nie zginę (BŚ 193).

Interesujący komentarz podany przez wydawców pokazıje, że pieśí pelnila w swoim czasie wyjątkową rolę:

W latach stalinowskich śpiewanie pieśniczek śląskich było niemile słyszane. Szerzono pieśni bojowe, rewolucyjne, partyzanckie. Asturia weszla do repertuaru chóru "Jutrzenka”, lecz wcale nie kojarzyla się bojszowianom z rewolucją hiszpańską, ale wyrażała tęsknotę za bliskim sercu Śląskiem (BŚ 193).

Fantazja lıdowa uczyniła bohaterem jednej z ballad króla S a rd y n i i :

150. Przez ten lasek rzymski

Jechal król sardyński,

I nadjechol grzecne dziewcę,

Zbierato pozimki (Lom 172).

Wypada spojrzé́ na zebrany material z lotu ptaka. Czy można coś powiedzieć na jego podstawie o stosunku mieszkańców Śląska do cudzoziennców? Przede wszystkim warto zauważyć, że pojawianie się w pieśniach nazw etnicznych wynika z różnych przyczyn. Niektórzy są wymieniani ze względu na wspólny los calcj wspólnoty (Niemıy), inni z powodu wydarzeń, o których wieści docierają na Śląsk (Belgia, I Iolandia). Pewne przeżycia związane z obcymi narodami dotyczą tylko niektórych Ślązaków - zołnierzy (wojny przeciw Francuzom albo marsze w armii austriackiej aż do Wloch). Cyganie i Żydzi są obecni w pieśniach jako mniejszości narodowe sąsiadıjące stale lub ustawicznie z mieszkańcami Śląska.

Interesujące wydają się te fragmenty, które mówią o wiązaniu się uczuciowym czy malżeńskim z przedstawicielani innych narodów. Niezależnie od tego, czy chodzi o wybór męża, czy żony, wymowa tych pieśni jest jednoznacznie negatywna. Odrzuca się Polaków 
(nr 5), Niemców (58-60), Francuzów (74), Cyganów (116-119) i Żydów (130-131). Ciekawe, że podobıe podejście prezentują nadal mlode dziewczyny ze Śląska:

Uważają one, że ich mężem powinien zostać Ślązak, a przynajmniej „żeby w żyłach przyszłego męża płynęła śląska krew po jednym z rodziców". Motywacja jest zazwyczaj następuljąca: Ślązak ze Ślązaczką lepiej się rozumieja (Krzyżyk, Synowiec 1997: 113).

Przy okazji przywołanych właśnie cytatów trzeba poruszyć wspomnianą już na wstępie kwestię wariantywności pieśniowych tekstów. Wyraźne jest to zwlaszcza przy porównaniu fragmentów $11 \mathrm{r} 58$ i 74, gdzie portret kandydata na męża jest identyczny, lecz raz odnosi się do Niemca, a raz — do Francuza. Jak się zdaje, narodowość jest tu muiej ważna od tego, że jest on cudzoziemcem. Podobną wymienność zauważany w balladzie o dziewczynie-drzewie. W jednym wariancie chcą to drzewo zrąbać Rusy (nr 134), a w imnch - Turcy (140-143)" .

Material pieśniowy prowokıje też do zastanowienia się, czy obraz cudzoziemców z punktu widzenia chlopskiego pokrywa się z ich widzeniem w polszczyźnie ogólnej i w literaturze pięknej. Częściowo się pokrywa, a częściowo - nie. Najbardziej te wizje różnią się w wypadku Francuzów. Wszystkie pieśni zebrane na Sląsku mówią o nich jako o groźnych wrogach wojennych, którzy zadają śmierć. Natomiast oficjalny stereotyp Francuza w kulturze polskiej nie zawiera wcale elementów negatywnych. Przypomnijmy chociażby tytul artykulu w zbiorze Narody i stereotypy: Polacy i Francuzi - mitosc (praurie) doskonata i fragment tego tekstu:

Wspólna historia niezakłócona ani jedną wojną, wspólni wladcy, ta sama religia, co nader istotne w procesie formowania się obu państw, a ponadto wiele podobieństw charakterologicznych pomiędzy dwoma narodami, wynikających, według niektórych, z lacińskiego temperamentı, z jego radością życia, poczuciem humoru i umilowanien rozkoszy stolu (Nowicki 1995: 165).

Można sądzić, że zbyt często zapomina się o „niższych” warstwach spoleczeństwa, o tych ludziach, którzy nie mieli swoich pisarzy, poetów, publicystów. A przecież naród składa się nie tylko z tych wykształconych. WXIX wieku składał się z poddanych rosyjskich, pruskich i austriackich, odbywających służbę wojskową w tych trzech armiach i maszerujących w obcych mundurach na różne wojny, które stawały się potem kanwą dla pieśni śpiewanych

\footnotetext{
"Wymicnnością ctnonimów w przyslowiach zajçłam się w artykulc: Tyrpa 200)3.

"2 W tym micjscu przywolajmy refleksj̧ badaczki motywu wojen tureckich w pieśniach : „Spojrzenic na wojny i w ogóle na dzieje z perspektywy ludowej jest niczmiernic interesujące i pouczające dla historyka. To, co wielkie i wspaniale dla wladców tego świata. często nie musi takic być i nie jest dla maluczkich" (Czamańska 200)1: 296).
} 
po polsku' ${ }^{2}$. Postulując badanie dialektów dla poznania wzajemmych odniesień narodów do siebie, Tomasz Szarota (1996: 66) pisze: „zapis dotyczy języka, jakim posługują się warstwy ludowe, czyli większość społeczeństwa”. Nazwano też kulturę ludową - kulturą milczącej większości (Pomorski 20)4: 28). Warto się czasem wsłuchać w glos tej milczącej większości, a głos ten to między innymi pieśni lıdowe.

\section{Źródła}

BŚ - A. Lysko, J. Wala, Bojszon'y śpicu'aja, Bojszowy 1998;

K 43 Śl - O. Kolberg, Dzieła w'systkie, t. 43: Ślask, opr. J. Szajbel, B. Linette, red. A. Skrukwa, E. Krzyżaniak, Wroclaw 1965;

Lom - J. Lompa, Pieśni ludu polskiego, opr. B. Zakrzewski, Wrocław 1970);

NK - Nou'a ksiegga przystón' i u'yraźn przystouiou'ych polskich, red. J. Krzyżanowski, t. 3, Warszawa 1972;

PG - Pieśni gónnicze, wyb. i opr. A. Dygacz, Katowice 1995;

PK - Piésui katou'ickie, wyb. i opr. A. 1)ygacz, Katowice 1996:

PL - Śpieu'nik pieśni lublinieckich, wyb. i opr. A. Dygacz, Katowice 1999;

PP — Pieśni poustancze, wyb. i opr. A. Dygacz, Katowice 1997;

PŚ - Pieśni ludou'e z polskiego Śląsa, t. 1, wyd. J. S. Bystroń, Kraków 1934; t. 2-3, wyd.

J. Ligęza, S. M. Stoiński, Kraków 1938-1939;

PW - Śląkice pieśni ludou'e ze zbiorón rękepiśmiénnyeh Stanistan'a Wrallisa, opr. K. Turek, Katowice 2000 ;

Rog - J. Roger, Pieśni ludu polskiego " Gómpm Szlaskn. Wroctaw 1863 [wyd. fototyp.: Opole 1976, wst. P. Świerc];

RŚ - A. Dygacz, Rozśpicu'any' Śląs, Chorzów [20)2];

ŚP - Slaskie pieśni ludou'é, wyb. i opr. A. Dygacz, Katowice 1995;

ZB IX 173-299 - A. Cinciała, Pieśni hudu śląikiego z okolic Cieszyna, „Zbiór Wiadomości do Antropologii Krajowej” t. 9, Kraków 1885.

\section{Literatura}

Bartmiński J. 1973 - O jezyku folklorn, Wroclaw;

Bystroní J. S. 1924 - Pieśni ludu polskiego, Kraków;

Czamańska I. 2001 - Wojny tureckic XII-XI'II wicku u' piesuniad narodou'ości Europy potudniou'ouschodnicj i środkou'ej, „Napis”, seria 7, s. 281-296;

Grybosiowa A. 1997 - J̨z)kou'o-kulturou'y u'izerumek Ślqzaka na te u'zérunku obu sąsiadóu', w: Polszczyzna śląska. Historia i wspótczesność, red. B. Wyderka, Opole, s. 83-90;

Krzyżyk D., Synowiec II. 1997 - Jezykou'a projekcja domu rodzinnego w' w'you'iedziach dorastających dzicu'zat, w: Dom u' jezy'kn i kulturze', red. G. Sawicka, Szczecin, s. 109-119; 
Mirga A., Mróz L. 1994 - Clyganie. Odmienność i nietolerancja, wst. ks. J. Tischner, Warszawa; Niewiara A. 2000 - Wyobrażenia o narodad u' pamiętnikach i dziennikach z XVI-XIX wieku, Katowice;

Nowicki J. 1995 - Polac) i Francuzi - mitość (prawic) doskonała, z franc. tt. U. Kropiwiec, w: Narody' i stereoty'py', red. T. Walas, Kraków, s. 165-176;

Ong W. 1992 - Oralność i piśmienność. Ston'o poddane technologii, tl. j wst. J. Japola, Lublin;

Pomorski J. 2004 - Punkt widze'nia w'e wspótczesnej historiografii, w: Punkt widzenia w jezzyku i u' kulturze, red. J. Bartmiński, S. Niebrzegowska-Bartmińska, R. Nycz, Lublin, s. 11-32; Szarota T. 1996 - Niency i Polacy. Wzajemme postrzeganie i stereotypy, Warszawa;

Tyrpa A. 2003 - Etnocentryczne widzenie obcych u' polszczyźnic ludouej, w: „Studia Dialektologiczne" t. 3, red. J. Okoniowa, Kraków [w druku]. 